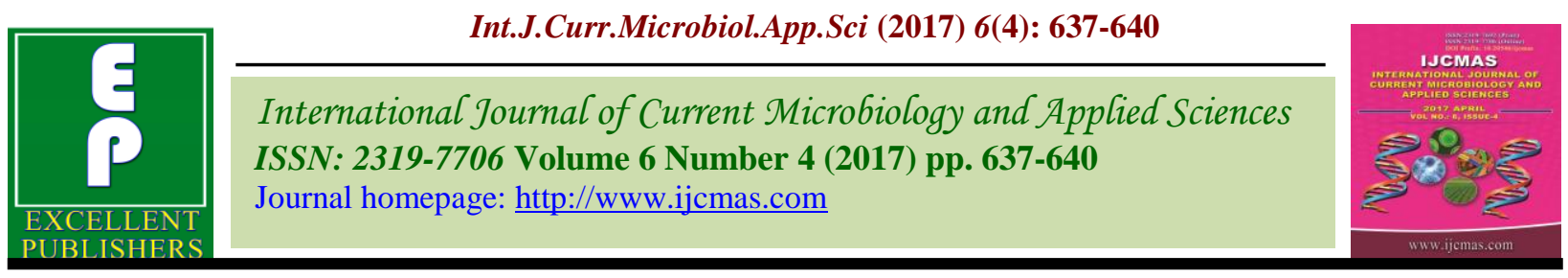

Original Research Article

https://doi.org/10.20546/ijcmas.2017.604.078

\title{
Determinants of Usefulness of Course Curriculum in a SAU as Perceived by Teachers
}

\author{
G. Pallavi* and K. Venkata Ranga Naika \\ Department of Agricultural Extension, UAS, GKVK, Bangalore-560 065, India \\ *Corresponding author
}

\begin{tabular}{|c|c|}
\hline & A B S T R A C T \\
\hline $\begin{array}{l}\text { Ke y w o r d s } \\
\text { Education, } \\
\text { Curriculum, } \\
\text { teachers } \\
\text { Courses, SAU. }\end{array}$ & $\begin{array}{l}\text { Quality education is an important prerequisite for the improvement of education system in } \\
\text { India. Education is basic requirement of the development of a nation. Hence, the teachers } \\
\text { need to equip themselves for the updating of courses to the students. In ancient to above, } \\
\text { study was conducted in University of Agricultural Sciences (UAS), Bangalore, Karnataka, } \\
\text { during the year } 2010-2011 \text {. The study revealed that } 45.00 \text { per cent of the teachers were } \\
\text { middle age, } 38.33 \text { per cent had } 11 \text { to } 20 \text { years of experience, More than half of the teachers }\end{array}$ \\
\hline Article Info & $\begin{array}{l}\text { had doctoral degree, three-fourth of them had undergone trainıngs and Correlation and } \\
\text { Multiple regression analysis of independent variables with perceived usefulness of }\end{array}$ \\
\hline $\begin{array}{l}\text { Accepted: } \\
\text { 06 March } 2017 \\
\text { Available Online: } \\
10 \text { April } 2017\end{array}$ & $\begin{array}{l}\text { curriculum by teachers was found to be significant at } 0.01 \text { and } 0.05 \text { level of significance } \\
v i z . \text { physical facilities, work load and organizational participation. The obtained results } \\
\text { clearly indicated that there is a need for proper reorientation of course curriculum in the } \\
\text { upcoming years. }\end{array}$ \\
\hline
\end{tabular}

\section{Introduction}

The spectacular growth in Agriculture has been due to account of development of skilled human resource, which plays a major role in developing technologies, their assessment and dissemination to farming community. Teachers in Agricultural universities by and large have good knowledge in their field of specialization, but seem to lack the ability, the ways and means of imparting it effectively. Therefore, the fourth Deans' Committee (Anonymous, 2007) is in the series which unlike earlier committees, has been given wide terms of reference, so that a holistic approach emerges for quality assurance in Agriculture Education while addressing the contemporary challenges for employability of passing out graduates. The recommendations have been made with a view to reorient course curricula to develop much needed skills and entrepreneurial mind set among the Under-Graduates to take up self employment, contribute to rural livelihood and food security, sustainability of Agriculture and be propeller for Agricultural transformation. Therefore, reforms in curriculum from time to time are very crucial to achieve quality in education and should be relevant to the changing needs of present and in the future.

\section{Materials and Methods}

The present investigation was carried out at University of Agricultural Sciences (UAS), Bangalore covering five campuses relating to 
Agriculture Discipline viz., College of Agriculture, GKVK, Bangalore, College of Agriculture, Mandya, College of Agriculture, Shimoga, College of Agriculture, Hassan and College of Sericulture, Chintamani (Chikkaballapur district). Ex-post-facto research design was employed for conducting the study. The respondents numbering 60 were selected randomly. A well structured, pre-tested questionnaire was used to collect the data. The responses were scored, quantified, categorized and tabulated using statistical methods like percentage, mean and standard deviation, frequencies, chi-square and correlation.

\section{Results and Discussion}

Nearly, 45.00 per cent of the teachers belong to middle age group, 33.33 per cent and 21.67 per cent were young age and old age group respectively. Majority of the teachers, 38.33 per cent had 11 to 20 years of experience. Whereas, 33.33 per cent had 10 years of experience and only 28.34 per cent had more than 20 years of experience. More than half (56.67 per cent) of the teachers had doctoral degree as their educational qualification, whereas 31.67 per cent had M.Sc. (Agri.) and only 11.66 per cent had additional qualification. Nearly three-fourth (73.33 per cent) of the teachers had undergone trainings, 50.00 per cent attended one training and 26.67 per cent had not undergone any training. Two-fifth of the teachers opined that physical facilities in the colleges were adequate, 31.67 per cent as more adequate and 28.33 per cent of the teachers perceived as inadequate. Majority of the teachers had medium level of organizational participation, whereas 18.33 per cent, 3.33 per cent and 35.00 per cent had low, high and no participation (Table 1).

Table.1 Profile of teachers

\begin{tabular}{|c|c|c|c|c|}
\hline Sl.No. & Variables & Category & No. & Per cent \\
\hline \multirow[t]{3}{*}{1} & \multirow[t]{3}{*}{ Age } & Young (Upto $35 \mathrm{yrs}$ ) & 20 & 33.33 \\
\hline & & Middle $\quad(36-45$ yrs $)$ & 27 & 45.00 \\
\hline & & Old (Above 45 yrs) & 13 & 21.67 \\
\hline \multirow[t]{3}{*}{2} & \multirow{3}{*}{$\begin{array}{l}\text { Professional } \\
\text { experience }\end{array}$} & Upto 10 years & 20 & 33.33 \\
\hline & & 11 to 20 years & 23 & 38.33 \\
\hline & & More than 20 years & 17 & 28.34 \\
\hline \multirow[t]{3}{*}{3} & \multirow{3}{*}{$\begin{array}{l}\text { Educational } \\
\text { qualification }\end{array}$} & i) Post graduates M.Sc. (Ag.) & 19 & 31.67 \\
\hline & & ii) Doctoral degrees M.Sc. (Ag.) and Ph.D. & 34 & 56.67 \\
\hline & & iii) With additional qualification & 7 & 11.66 \\
\hline \multirow[t]{6}{*}{4} & \multirow{6}{*}{$\begin{array}{l}\text { Training } \\
\text { undergone }\end{array}$} & Training attended & 44 & 73.33 \\
\hline & & Not attended & 16 & 26.67 \\
\hline & & Attended one training & 30 & 50.00 \\
\hline & & Two trainings & 10 & 16.67 \\
\hline & & Three trainings & 2 & 3.33 \\
\hline & & More than three & 2 & 3.33 \\
\hline \multirow[t]{3}{*}{5} & \multirow{3}{*}{$\begin{array}{l}\text { Physical } \\
\text { facilities }\end{array}$} & More adequate & 19 & 31.67 \\
\hline & & Adequate & 24 & 40.00 \\
\hline & & Inadequate & 17 & 28.33 \\
\hline \multirow[t]{4}{*}{6} & \multirow{4}{*}{$\begin{array}{l}\text { Organizational } \\
\text { participation }\end{array}$} & Low & 11 & 18.33 \\
\hline & & Medium & 26 & 43.34 \\
\hline & & High & 2 & 3.33 \\
\hline & & No participation & 21 & 35.00 \\
\hline
\end{tabular}


Table.2 Distribution of teachers with respect to work load

\begin{tabular}{|c|l|c|c|}
\hline SI.No. & \multicolumn{1}{|c|}{ Category } & No. & Per cent \\
\hline 1 & Heavy & 15 & 25.00 \\
\hline 2 & Optimum & $\mathbf{3 4}$ & $\mathbf{5 6 . 6 7}$ \\
\hline 3 & Light & 11 & 18.33 \\
\hline Total & 60 & 100.00 \\
\hline
\end{tabular}

Table.3 Relationship between independent variables and perceived usefulness of curriculum by teachers

\begin{tabular}{|c|l|c|}
\hline \multicolumn{2}{|c}{ Independent Variables } & 'r' value \\
\hline Sl.No. & \multicolumn{1}{|c|}{ 'r 60$)$} \\
\hline 1 & Age & $0.127 \mathrm{NS}$ \\
\hline 2 & Educational qualification & $-0.080 \mathrm{NS}$ \\
\hline 3 & Experience & $0.437 *$ \\
\hline 4 & Training attended & $-0.016 \mathrm{NS}$ \\
\hline 5 & Physical facilities & $0.631 * *$ \\
\hline 6 & Work load & $-0.399 *$ \\
\hline 7 & Organizational participation & $0.479 *$ \\
\hline
\end{tabular}

Table.4 Multiple regression analysis of independent variables with perceived usefulness of curriculum by teachers

$(\mathrm{n}=60)$

\begin{tabular}{|c|l|c|c|c|}
\hline Sl.No. & Independent Variables & B & Std error & 't' values \\
\hline 1 & Age & 0.096 & 0.082 & $1.175 \mathrm{NS}$ \\
\hline 2 & Educational qualification & 0.245 & 0.221 & $1.127 \mathrm{NS}$ \\
\hline 3 & Experience & -0.240 & 0.118 & $-2.042^{*}$ \\
\hline 4 & Training attended & 0.006 & 0.085 & $0.070 \mathrm{NS}$ \\
\hline 5 & Physical facilities & 0.247 & 0.069 & $3.567 * *$ \\
\hline 6 & Work load & -0.130 & 0.053 & $-2.468^{*}$ \\
\hline 7 & Organizational participation & 0.179 & 0.055 & $3.278^{* *}$ \\
\hline
\end{tabular}
$\mathrm{R}^{2}=0.499$ Fignificant at 0.01 level, * Significant at 0.05 level
* NS - Non-significant

More than half (56.67 per cent) of the teachers had optimum work load, 25.00 per cent had heavy work load and only 18.33 per cent of the teachers had light work load (Table 2). The obtained results clearly showed that the teachers need to equip themselves for the updating of courses to the students and adopt the new audio visual aids for the better teaching effectiveness. The correlation values with respect to teacher's variables viz., physical facilities, work load and organizational participation had a significant relationship with the perception at 0.01 and 0.05 level (Table 3). The regression coefficients $R^{2}=0.499$ was found variation with independent variables of teachers and the variables viz., physical facilities and organizational participation was found significant at 0.01 level whereas experience and work load variables was significant at 0.05 level (Table 4). Most of the variables showed significant results, hence teachers 
need to encouraged themselves to attend professional development training and incorporate more hands-on activities into the curriculum.

In conclusion teachers should be encouraged to attend professional development training and incorporate more hands-on activities into the curriculum. With fast emerging technologies in every field, training is increasingly becoming a potent instrument that can help people bring about improvements in their prevailing conditions and ways of making a living.

\section{References}

Anonymous. 2007. Report of fourth deans committee on Agricultural Education in India. Guidelines for assessing training needs and performance of teaching faculties, Education Division, ICAR, New Delhi. P: 106-107.

\section{How to cite this article:}

Pallavi, G. and Venkata Ranga Naika, K. 2017. Determinants of Usefulness of Course Curriculum in a SAU as Perceived by Teachers. Int.J.Curr.Microbiol.App.Sci. 6(4): 637-640. doi: https://doi.org/10.20546/ijcmas.2017.604.078 